\title{
Immunoexpression of p53 in Oral Squamous Cell Carcinoma and Oral Dysplastic Lesions in Patients with the Habit of Reverse Smoke
}

\author{
Inmunoexpresión de p53 en Carcinoma Bucal Escamo Celular \\ y Displasias Orales en pacientes con el Hábito de Fumar Invertido
}

\author{
Efraín Álvarez Martínez; Raul Jiménez-Gómez" \& Carlos Martin Ardila Medina***
}

\begin{abstract}
ÁLVAREZ, M. E.; JIMÉNEZ-GÓMEZ, R. \& ARDILA, M. C. M. Immunoexpression of p53 in oral squamous cell carcinoma and oral dysplastic lesions in patients with the habit of reverse smoke. Int. J. Odontostomat., 7(2):185-191, 2013.

ABSTRACT: Molecular biological markers have been suggested to be of value in the diagnosis and prognostic evaluation of precancerous lesions. The purpose of the current study was to investigate the expression of p53 protein in normal oral mucosa, oral dysplastic lesions (DL), and oral squamous cell carcinoma (SCC), comparing patients with the habit of reverse smoking and conventional smokers. The patients were subjected to incisional biopsy and the soft tissue specimens were routinely fixed in $10 \%$ formalin and processed in the laboratory. Immunohistochemical technique was performed using the avidin-biotin-peroxidase protocol. The 102 patients included 42 reverse smokers and 60 conventional smokers. There were 79 cases of mild, 15 of moderate, and 3 of severe epithelial dysplasia. Five microinvasive oral SCC included one male and four females. The clinical characteristics of microinvasive tumors included patches, plaques or erosions; $100 \%$ showed positive nuclear staining for p53. It was found a significant association of p53 expression and exposure of reverse smoking among microinvasive oral SCC and oral DL patients in the population studied.
\end{abstract}

KEY WORDS: p53, immunohistochemistry, oral squamous cell carcinoma, reverse smoker.

\section{INTRODUCTION}

Squamous cell carcinoma (SCC) of the mouth constitutes the fifth most common cancer worldwide, and the third most common in developing countries (Abbas et al., 2007). Many oral carcinomas are preceded by clinically evident premalignant lesions. These lesions show varying degrees of epithelial dysplasia, from mild to severe. However, predicting the behavior of dysplasia is difficult since histological characterization may not always provide prognostic information (Pendfold et al., 1996).

Molecular biological markers have been suggested to be of value in the diagnosis and prognostic evaluation of precancerous lesions. p53 is the name of the tumor suppressor gene located on short arm of chromosome 17 , as well as the protein encoded by this gene. Many recent studies have focused on the p53 tumor suppressor gene, analyzing its gene and protein status. The immunohistochemical analysis of p53 protein is an uncomplicated method that has been broadly used; many studies have shown that $\mathrm{p} 53$ protein is implicated in oral carcinogenesis and its alteration occurs early in the progression of neoplastic transformation, frequently preceding identifiable histological alterations. Also, in oral premalignant lesions, expression of p53-positive cells in the suprabasal layers of the epithelium has been seen as an indication of impending malignant development (Nylander et al., 2000). The prevalence of p53 expression varies among reports; local oral habits practiced in diverse geographical regions have been suggested to be responsible for this variability (Kerdpond et al., 1997, 2001).

\footnotetext{
* Oral and Maxillofacial Surgeon. Ph.D in Basic Biomedical Sciences. Titular Professor, School of Dentistry, University of Antioquia, Medellín, Colombia. "Master of Medical Science. Professor Stomatology and Maxillofacial Surgery Unit of the San Vicente de Paul University Hospital, Medellín, Colombia. "'Ph.D in Epidemiology. Chief of Stomatology Group Research. Titular Professor, School of Dentistry, University of Antioquia, Medellín, Colombia This study was supported by a grant from the Colombian Institute of Science and Technology "Francisco José de Caldas" COLCIENCIAS (grant 11504-16485).
} 
Consumption of tobacco can cause genetic and molecular alterations in clinically distinct oral premalignant lesions (Schmidt et al., 2004). Reverse smoking is an unusual tobacco habit performed by the smoker placing the lighted end of a cigarette inside the mouth; the seal provided bythe lips allows to the slow inhaling of the cigarette. This habit is practiced in various parts of the word, including The Netherlands, Southeast Asia, Indian subcontinent, Sri Lanka, Jamaica, Panama, Venezuela, Caribbean Islands and Colombia; occasionally immigrants to Western countries continue the habit of reverse smokers. In Colombia there are some very well defined regions with presence of this habit that seems to be transmitted through generations.

The clinical aspect of the oral mucosa in patients with the habit of reverse smoke varies when compared with conventional smokers. The most commonly affected areas are tongue and palate include both benign and malignant mucosal pathologies. Besides, reverse smoking is claimed to intensify the carcinogenic effect of heat and smoke resulting in increased risk of cancer development (Mercado-Ortiz et al., 1996).

To our knowledge no studies have examined the expression of p53 protein in oral dysplastic lesions (DL) and oral SCC, in patients with the habit of reverse smoking. Therefore, the aim of the present study was to investigate the expression of p53 protein in normal oral mucosa, oral DL, and oral SCC, using immunohistochemistry, comparing patients with the habit of reverse smoking and conventional smokers.

\section{MATERIAL AND METHOD}

This cross sectional study was performed during the first semester of 2009. An informative campaign was prepared through field advisors and community leaders of Hato Nuevo, San Francisco and Cayo de Palma villages, Sucre Department in Colombia, in order to notify the population about the investigation. Then, the researchers group visited the villages with the purpose of accomplish the epidemiologic gathering, to identify and select people with the habit of reverse smoking according to the criteria of inclusion (regular reverse smokers of any type of tobacco, during a period longer than 6 months, with a minimum dose of one cigarette per day). Conventional smokers also were included as control. This process was done with a home to home survey, with socio demographic variables, concerning attitudes and behaviors related with the use of tobacco.

All the 102 patients selected were subjected to incisional biopsy and the soft tissue specimens were routinely fixed in $10 \%$ formalin and processed in the laboratory (Pathology Department, School of Medicine of the University of Antioquia in Medellín, Colombia).

Dysplasia was classified as mild, moderate or severe following the WHO tumor classification (Gale et al., 2005). A representative block for each case was selected and multiple $4 \mu \mathrm{m}$ sections were cut. The remaining 15 specimens included cases with normal mucosa. Normal controls were selected based on no history of alcohol or tobacco use.

Hematoxylin and eosin stained sections were prepared from the paraffin blocks and examined to determine the histologic tumor type, grade of tumor differentiation, depth of tumor invasion, and to assess the degree of dysplasia in the oral DL (Gale et al.).

Immunohistochemical technique was performed using the avidin-biotin-peroxidase protocol, according to Abrahao et al. (2011). Briefly, antigen retrieval was performed with Target antigen retrieval solution $\mathrm{pH} 9$ (Dako A/S, CA, USA) in a water bath, followed by incubation with $6 \%$ hydrogen peroxide to quench endogenous peroxidase. The sections were then incubated in blocking solution ( $3 \%$ bovine serum albumin) for 1 hour at room temperature, followed by primary antibody incubation, previously diluted in blocking solution. Anti-p53 (clone DO-7, 1:200 dilution - DAKO A/S, CA, USA) antibody was incubated for 30 minutes at room temperature. Sections were exposed to the LSABTM system (DAKO A/S, CA, USA), developed in diaminobenzidine (Dako A/S, CA, USA) and counterstained in Mayer's hematoxylin.

For the antibody, positive and negative controls were used. Two independent observers reviewed the immunohistochemically-stained sections. In normal mucosa and dysplasia, p53, according to Cruz et al. (1998) and to Pirog et al. (2002) were classified as positive or negative, attributing a score taking into account both the relative number of stained nuclei and their localization in the upper $2 / 3$ of the epithelium. In the carcinomas, evaluation was made in the areas of infiltration, where cell proliferation was more active. Breast tumor tissue which had previously been identified as p53 immunopositive was used as a positive control. 
On admission the patients gave their consent to use the data obtained during the examination and treatment for further scientific projects. The study design was approved by the Ethics Committee on Human Research of the School of Dentistry of the University of Antioquia according to the Declaration of Helsinki.

Data collected were analyzed using the statistical package for social sciences (SPSS) for Windows version 19. Data was summarized in form of proportions and frequency tables for categorical variables. Means, median and standard deviation were used to summarize continuous variables. The Chi-Square test was used to compare the counts of categorical response between two independent variables. The statistical significance was fixed at 0.05 .

\section{RESULTS}

This study was performed on resection specimens from five oral microinvasive SCC and 97 biopsies from oral DL. The 102 patients included 42 $(41.2 \%)$ reverse smokers and 60 (58.8\%) conventional smokers. Fifteen normal samples of oral mucosa were used as control. A total of 41 reverse smokers were women, while there were no gender differences in conventional smokers. Reverse smokers revealed a longer duration of smoking (32.7 \pm 18 years) than conventional smokers $(30.2 \pm 15$ years).

There were 79 cases of mild, 15 of moderate, and 3 of severe epithelial dysplasia. In all cases, consensus on the grading of dysplasia was achieved following review. Five microinvasive oral SCC included one male (conventional smoker) and four females (reverse smokers). In the present study, the clinical characteristics of microinvasive tumors included patches, plaques or erosions rather than ulcers or verrucous lesions.

p53 was confined to the basal layer in the normal oral epithelium (Fig. 1). In oral DL, p53 was present in the basal and suprabasal layers (Fig. 2). Of the five microinvasive oral SCC, $100 \%$ showed positive nuclear staining for p53 (Fig. 3).

In the 97 oral DL, p53 was immunoexpressed in $74 \%$ and $78 \%$ of the reverse and conventional smokers respectively.

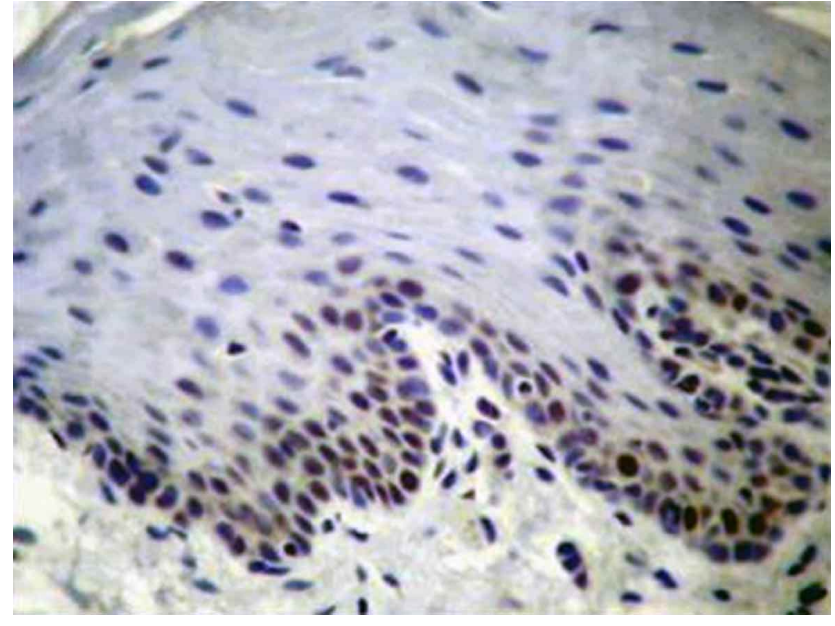

Fig. 1. Normal oral mucosa showing basal cells positive for p53.

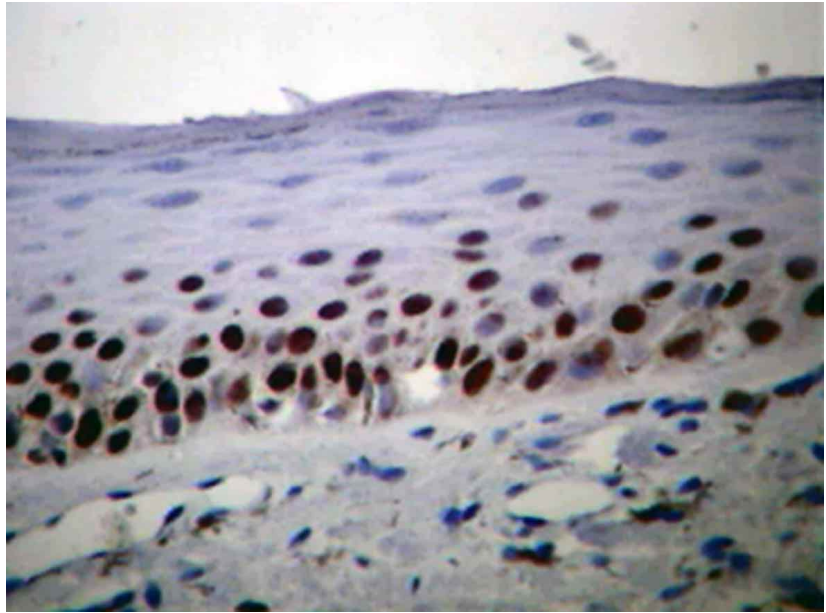

Fig. 2. Oral dysplasia showing p53 in basal and suprabasal layers.

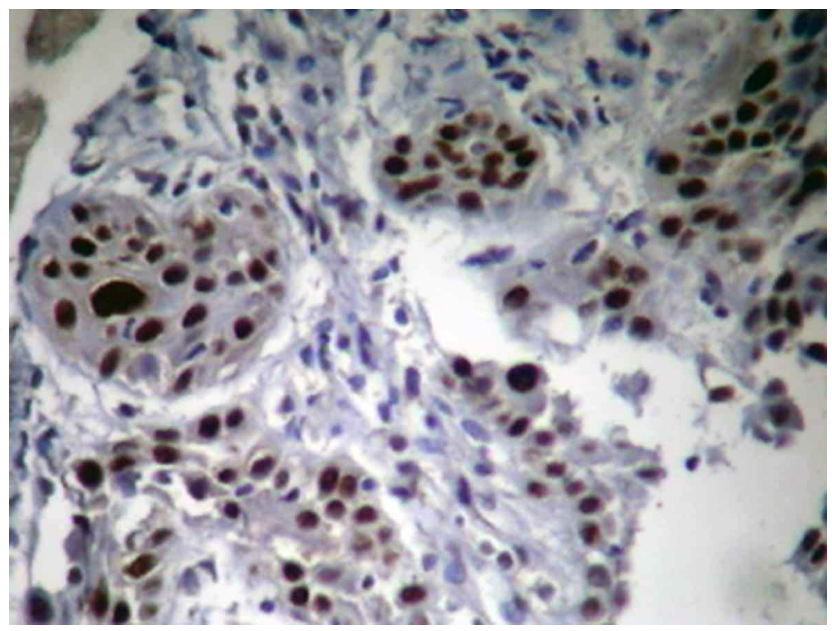

Fig. 3. Microinvasive oral squamous cell carcinoma showing high percentage of p53 expression. 
Table I. p53 immunoexpression patterns in relation to the smoking habits, gender, age and grade of dysplasia. $\mathrm{n}=97$

\begin{tabular}{llccc}
\hline \multirow{2}{*}{ Factor } & & \multicolumn{2}{c}{ p53 } & \multirow{2}{*}{ p value } \\
\cline { 3 - 4 } & & Positive & Negative & \\
\hline \multirow{2}{*}{ Sex } & Female & 55 & 8 & $<0.0001$ \\
\multirow{3}{*}{ Age } & Male & 24 & 10 & $<0.0001$ \\
\multirow{3}{*}{ Smoking } & $\leq 50$ & 25 & 10 & $<0.0001$ \\
& $>50$ & 54 & 8 & $<0.0001$ \\
\multirow{2}{*}{ Grade of dysplasia } & Reverse & 31 & 6 & $<0.0001$ \\
& Conventional & 48 & 12 & $<0.0001$ \\
& Mild & 63 & 16 & $<0.0001$ \\
& Moderate/Severe & 16 & 2 & $<0.0001$ \\
\hline
\end{tabular}

Table II. p53 immunoexpression patterns in relation to the smoking habits, gender, age in oral squamous cell carcinoma. $n=5$

\begin{tabular}{llccc}
\hline \multirow{2}{*}{ Factor } & & \multicolumn{2}{c}{ p53 } & p value \\
\cline { 3 - 4 } & & Positive & Negative & \\
\hline \multirow{2}{*}{ Sex } & Female & 4 & 0 & $<0.0001$ \\
\multirow{3}{*}{ Age } & Male & 1 & 0 & $<0.0001$ \\
& $\leq 50$ & 1 & 0 & $<0.0001$ \\
\multirow{4}{*}{ Smoking } & $>50$ & 4 & 0 & $<0.0001$ \\
& Reverse & 4 & 0 & $<0.0001$ \\
& Conventional & 1 & 0 & $<0.0001$ \\
\hline
\end{tabular}

progression to oral SCC (Montebugnoli et al., 2008). Moreover, the advantage of immunohistochemical staining is the direct demonstration of the spatial relationship of cells that have altered p53 protein expression, which is of particular importance in the study of clonal expansion of altered cell populations during multistage tumor genesis (Kushner et al., 1997).

In this study, p53 expression was

\section{DISCUSSION}

The pattern of immunoexpression of p53 has been studied in a broad diversity of investigations (Abbas et al.; Kerdpon et al., 2001; Abrahao et al.). However, the current study has a particular interest because it investigates the expression of p53 in SCC and DL of reverse smokers which was not previously reported to date. In those countries where reverse smoking is practiced, a wide range of oral tissue changes have been observed (Mercado-Ortiz et al.; Alvarez-Gómez et al., 2008), including both benign and malignant oral mucosa pathologies. This different form of tobacco habit has been shown to be associated with oral cancer and precancerous lesions confirming our results (Alvarez-Gómez et al.). The evidence that the p53 pathway is very important in the biology of oral cancer has led to the application of such immunohistochemical analysis as a simple rapid and inexpensive method to potentially malignant lesions in an attempt to find a useful marker to predict confined to the basal cell layer of normal oral mucosa. In the dysplastic group, p53 was expressed in the basal and suprabasal layers, whereas the five microinvasive oral SCC showed positive nuclear staining for $p 53$. Diverse investigations revealed comparable findings (Cruz et al.; lamaroon et al., 2004). p53, when detected in oral mucosa without malignant potential was interpreted as physiological response of cells to genotoxic stress (Cruz et al.). In contrast, p53 expression in suprabasal cells was only detected in premalignant lesions, reflecting the presence of proliferating cells with DNA damage in more superficial layers of the epithelium (lamaroon et al.).

To our knowledge this is the first investigation that founded p53 expression in microinvasive oral SCC. Our study revealed that in microinvasive carcinoma, the number of specimens positive for p53 was higher in comparison with the dysplastic lesions. In this respect, Warnakulasuriya \& Johnson (1992) reported that positive included carcinomas without 
deep invasion suggesting that p53 mutation may occur in the early stages of progression of a malignancy. Pentenero et al., (2011) found one cancer-related death observed in patients with oral microinvasive lesions. Additionally, they indicated that microinvasive carcinomas were diagnosed incidentally through a habitual clinical evaluation or during a follow-up of a premalignant lesion, rather than due to the presence of symptoms. Confirming our results, a previous investigation showed that microinvasive SCC had similar clinical aspects (erosions, patches and plaques) to our findings. As microinvasive lesions tend to present clinically as premalignant lesions, accurate clinical examination is essential if misdiagnosis of early lesions is to be avoided (Pentenero et al.).

In the present study, p53 was established in $74 \%$ and $78 \%$ of the oral dysplastic lesions in reverse and conventional smokers, respectively. This result confirms the previous reports which assumed that expression of p53 in the premalignant oral lesions may be an early episode in oral carcinogenesis (Ralhan et al., 2000). Consequently, the expression of p53 in the oral DL may facilitate in identifying patients who are at high risk for cancer development. This statement is supported by a follow-up study that found that no one of the p53 negative oral DL progressed to cancer, while three of the 26 p53 positive dysplasias developed cancer (Rich et al., 1999). Consistently, Cruz et al. observed that $86 \%$ of premalignant lesions that showed p53 expression above the basal layer developed into SCC.

In this sample, $82 \%$ of cases stained positive for $p 53$. The high prevalence is comparable with those reported previously (Kerdpon et al., 1997; Ralhan et al.). Our finding is a result of the high prevalence of p53 expression associated with the habit of smoking tobacco, where reverse smokers increased significantly this high frequency. This is consistent with Field et al. (1994) who analyzed the smoking history of 71 patients by logistic regression and found that smoking correlates with p53 overexpression. Similarly, increased $p 53$ positive cells were detected in patients with both betel quid chewing and smoking habits (Humayun \& Prasad, 2011).

An important finding in our work is that reverse smokers were positively correlated with p53 expression and consequently with a higher number of oral DL and SCC. Some studies may explain this information. Quigley et al. (1965) showed that the maximum internal cigarette temperature in seven reverse smoking experiments was $760^{\circ} \mathrm{C}$. The reverse smoking experiments lasted longer; in practice reverse smoking lasts as long as $18 \mathrm{~min}$. Therefore, palatal temperatures rise appreciably during reverse smoking, indicating that substantial infrared inputs occur and transient tissue dehydration takes place. In line with this fact, White et al. (2001) found that tobacco heated to temperatures of $475^{\circ} \mathrm{C}$ or greater generated smoke aerosol that was detectably mutagenic. However, the relevance of these findings regarding cancer risk in humans is difficult to assess because of the lack of a direct correlation between mutagenicity and carcinogenicity (White et al.) Further investigations about the relationship between p53 and reverse smoking are needed to provide more understanding of habit-related oral carcinogenesis.

In this study, females were more affected with the premalignant and malignant lesions than males, because traditionally females are more likely to display reverse smoking. The fact that reverse smoking is predominantly a female habit is possibly a consequence of some of the sociologic roles played by women in cultures where this habit is observed (Mercado-Ortiz et al.; Alvarez-Gómez et al.).

The relationship of p53 expression and clinicopathological parameters has been reported with variable results. Most studies found no correlation of p53 expression with age, sex, site, disease stage and tumor differentiation (Rowley et al., 1997; Yao et al., 1999) while some reported a relation with tumor differentiation ( $\mathrm{Ng}$ et al., 1999).

In conclusion, the present study found a significant association of p53 expression and exposure of reverse smoking among microinvasive oral SCC and oral DL patients in the population studied. Additionally, the significant correlation between progression of oral epithelium from normal to neoplasia and increased expression of p53 suggests that it may be useful biomarker of malignant transformation in oral precancerous lesions and may serve as transitional point for cancer prevention programs.

\section{ACKNOWLEDGEMENTS}

This study was supported by a grant from the Colombian Institute of Science and Technology "Francisco José de Caldas" COLCIENCIAS (grant 115-0416485) 
ÁLVAREZ, M. E.; JIMÉNEZ-GÓMEZ, R. \& ARDILA, M. C. M. Inmunoexpresión de p53 en carcinoma bucal escamo celular y displasias orales en pacientes con el hábito de fumar invertido. Int. J. Odontostomat., 7(2):185-191, 2013.

RESUMEN: Marcadores biológicos moleculares se han sugerido para ser de valor en el diagnóstico y evaluación pronóstica de lesiones precancerosas. El propósito del presente estudio fue investigar la expresión de la proteína p53 en mucosa oral normal, lesiones displásicas orales (LD), y en el carcinoma oral de células escamosas (COCC), comparando pacientes con el hábito de fumar convencional y fumar invertido. Los pacientes fueron sometidos a biopsia por incisión y los especímenes de tejidos blandos fueron fijados en formalina al $10 \%$ y se procesaron en el laboratorio. La técnica inmunohistoquímica se realizó utilizando el protocolo de avidina-biotina-peroxidasa. De los 102 pacientes incluidos, 42 fueron fumadores invertidos y 60 fumadores convencionales. Hubo 79 casos de displasia epitelial leve, 15 moderada, y 3 severa. Cinco casos de COCC microinvasivo incluyeron un hombre y cuatro mujeres. Las características clínicas de los tumores microinvasores incluyen parches, placas o erosiones; el 100\% mostró tinción nuclear positiva para p53. Se encontró una asociación significativa de la expresión de p53 y la exposición de los fumadores invertidos entre pacientes con COCC microinvasivo y DL en la población estudiada.

PALABRAS CLAVE: p53, inmunohistoquímica, carcinoma oral de células escamosas, fumador invertido.

\section{REFERENCES}

Abbas, N. F.; Labib El-Sharkawy, S.; Abbas, E. A. \& Abdel Monem El-Shaer, M. Immunohistochemical study of p53 and angiogenesis in benign and preneoplastic oral lesions and oral squamous cell carcinoma. Oral Surg. Oral Med. Oral Pathol. Oral Radiol. Endod., 103(3):385-90, 2007.

Abrahao, A. C.; Bonelli, B. V.; Nunes, F. D.; Dias, E. P. \& Cabral M. G. Immunohistochemical expression of p53, p16 and hTERT in oral squamous cell carcinoma and potentially malignant disorders. Braz. Oral Res., 25(1):3441, 2011.

Álvarez-Gómez, G. J.; Alvarez-Martínez, E.; Jiménez-Gómez, R.; Mosquera-Silva, Y.; Gaviria-Núñez, A. M.; GarcésAgudelo, A.; et al. Reverse smokers's and changes in oral mucosa. Department of Sucre, Colombia. Med. Oral Patol. Oral Cir. Bucal, 13(1):E1-8, 2008.

Cruz, I. B.; Snijders, P. J.; Meijer, C. J.; Braakhuis, B. J.; Snow, G. B.; Walboomers, J. M.; et al. p53 Expression above the basal cell layer in oral mucosa is an early event of malignant trasformation and has predictive value for developing oral squamous cell carcinoma. J. Pathol., 184(4):360-8, 1998.

Field, J. K.; Zoumpourlis, V.; Spandidos, D. A. \& Jones, A. S. p53 expression and mutations in squamous cell carcinoma of the head and neck: expression correlates with the patients' use of tobacco and alcohol. Cancer Detect. Prev., 18(3):197-208, 1994.

Gale, N.; Pilch, B. Z. \& Sidransky, D. Epithelial precursor lesions. In: Barnes, L.; Evenson, J.; Reichart, P. \& Sidransky, D. (Eds.). World Health Organization Classification of Tumours. Pathology and Genetics of Head and Neck Tumours. Lyon, IARC Press, 2005. pp.177-9.
Humayun, S. \& Prasad, V. R. Expression of p53 protein and ki-67 antigen in oral premalignant lesions and oral squamous cell carcinomas: An immunohistochemical study. Natl. J. Maxillofac. Surg., 2(1):38-46, 2011.

lamaroon, A.; Khemaleelakul, U.; Pongsiriwet, S. \& Pintong, J. Coexpression of p53 and Ki67 and lack of EBV expression in oral squamous cell carcinoma. J. Oral Pathol. Med., 33(1):30-6, 2004.

Kerdpon, D.; Sriplung, H. \& Kietthubthew, S. Expression of p53 in oral squamous cell carcinoma and its association with risk habits in southern Thailand. Oral Oncol., 37(7):553-7, 2001.

Kerdpon, D.; Rich, A. M. \& Reade, P. C. Expression of p53 in oral mucosal hyperplasia, dysplasia and squamous cell carcinoma. Oral Dis., 3(2):86-92, 1997.

Kushner, J.; Bradley, G. \& Jordan, R. C. Patterns of p53 and $\mathrm{Ki}-67$ protein expression in epithelial dysplasia from the floor of the mouth. J. Pathol., 183(4):418-23, 1997.

Mercado-Ortiz, G.; Wilson, D. \& Jiang, D. J. Reverse smoking and palatal mucosal changes in Filipino women. Epidemiological features. Aust. Dent. J., 41(5):300-3, 1996.

Montebugnoli, L.; Felicetti, L.; Gissi, D. B.; Cervellati, F.; Servidio, D.; Marchetti, C.; et al. Predictive Role of p53 Protein as a Single Marker or Associated to Ki67 Antigen in Oral Carcinogenesis. Open Dent. J., 2:24-9, 2008.

Ng, I. O.; Lam, K. Y.; Ng, M. \& Regezi, J. A. Expression of p21/waf1 in oral squamous cell carcinomas--correlation with $\mathrm{p} 53$ and $\mathrm{mdm} 2$ and cellular proliferation index. Oral Oncol., 35(1):63-9, 1999. 
ÁLVAREZ, M. E.; JIMÉNEZ-GómEZ, R. \& ARDILA, M. C. M. Immunoexpression of p53 in oral squamous cell carcinoma and oral dysplastic lesions in patients with the habit of reverse smoke. Int. J. Odontostomat., 7(2):185-191, 2013.

Nylander, K.; Dabelsteen, E. \& Hall, P. A. The p53 molecule and its prognostic role in squamous cell carcinomas of the head and neck. J. Oral Pathol. Med., 29(9):413-25, 2000.

Penfold, C. N.; Partridge, M.; Rojas, R. \& Langdon, J. D. The role of angiogenesis in the spread of oral squamous cell carcinoma. Br. J. Oral Maxillofac. Surg., 34(1):37-41, 1996.

Pentenero, M.; Navone, R.; Motta, F.; Marino, R.; Gassino, L.; Broccoletti, R.; et al. Clinical features of microinvasive stage I oral carcinoma. Oral Dis., 17(3):298-303, 2011.

Pirog, E. C.; Baergen, R. N.; Soslow, R. A.; Tam, D.; DeMattia, A. E.; Chen, Y. T.; et al. Diagnostic accuracy of cervical low-grade squamous intraepithelial lesions is improved with MIB-1 immunostaining. Am. J. Surg. Pathol., 26(1):70-5, 2002.

Quigley, L. F. Jr.; Cobb, C. M. \& Hunt, E. E. Jr. Measurement of oral and burning zone temperatures during conventional and reverse cigarette smoking. Arch. Oral Biol., 10:35-44, 1965.

Ralhan, R.; Sandhya, A.; Meera, M.; Bohdan, W. \& Nootan, S. K. Induction of MDM2-P2 transcripts correlates with stabilized wild-type p53 in betel- and tobacco-related human oral cancer. Am. J. Pathol., 157(2):587-96, 2000.

Rich, A. M.; Kerdpon, D. \& Reade, P. C. p53 expression in oral precancer and cancer. Aust. Dent. J., 44(2):102-5, 1999.

Rowley, H.; Helliwell, T. R.; Jones, A. S.; Roland, N. J.; Field, E. A. \& Field, J. K. An immunohistochemical analysis of p53 protein expression in pre-malignant and malignant tissues of the oral cavity. Clin. Otolaryngol. Allied Sci., 22(1):23-9, 1997.

Schmidt, B. L.; Dierks, E. J.; Homer, L. \& Potter, B. Tobacco smoking history and presentation of oral squamous cell carcinoma. J. Oral Maxillofac. Surg., 62(9):1055-8, 2004.

Warnakulasuriya, K. A. \& Johnson, N. W. Expression of p53 mutant nuclear phosphoprotein in oral carcinoma and potentially malignant oral lesions. J. Oral Pathol. Med., 21(9):404-8, 1992.

White, J. L.; Conner, B. T.; Perfetti, T. A.; Bombick, B. R.; Avalos, J. T.; Fowler, K. W.; et al. Effect of pyrolysis temperature on the mutagenicity of tobacco smoke condensate. Food Chem. Toxico., I 39(5):499-505, 2001.

Yao, L.; Iwai, M. \& Furuta, I. Correlations of bcl-2 and p53 expression with the clinicopathological features in tongue squamous cell carcinomas. Oral Oncol., 35(1):56-62, 1999.
Correspondence to:

Carlos M. Ardila

Calle 64 Nº 52-59, Medellín

COLOMBIA

Telephone: 57-4-2196760

Fax: 57-4-2195332

Email: martinardila@gmail.com

Received: 11-02-2013

Accepted: 30-04-2013 